\title{
PATHOGENESIS OF CHRONIC DISEASE ASSOCIATED WITH PERSISTENT LYMPHOCYTIC CHORIOMENINGITIS VIRAL INFECTION
}

\author{
I. Relationship of Antibody Production to Disease in \\ Neonatally Infected Mice*, $\ddagger$
}

By MICHAEL B. A. OLDSTONE, 8 M.D., AND FRANK J. DIXON, M.D.

(From the Department of Experimental Pathology, Scripps Clinic and Research Foundation, La Jolla, California 92037)

(Received for publication 22 October 1968)

It has been over $30 \mathrm{yr}$ since Traub first reported that lymphocytic choriomeningitis (LCM) virus could cause a life-long, symptomless infection in mice (1-5). The chronic LCM infection or carrier state develops in mice naturally infected in utero (6) or inoculated with LCM virus shortly after birth (7-9). In such carrier mice, high titers of virus in blood and organs continue through life in the absence of detectable circulating antibody. These facts led Burnet and Fenner to postulate that the congenital LCM infection induced immunologic tolerance to the virus (10). Recently, evidence has been presented to challenge this traditional concept of immunologic tolerance in the LCM carrier state. Oldstone and Dixon reported that anti-LCM antibody, while not detectable in the circulation, could be found in kidneys of LCM carriers along with LCM virus and complement (11). Controversy has also arisen over whether persistent LCM viral infection is accompanied by disease. Hotchin has described the occurrence of a late life or slow virus disease (12-14) in chronically infected mice while Mims (15) and Volkert (16), working independently, have not observed any such abnormalities.

This paper reports studies on chronic LCM infections in several murine strains. LCM carriers of some strains develop an associated chronic disease consisting of glomerulonephritis, focal hepatic necrosis, extensive lymphoid proliferation, and interstitial round cell infiltrations in many of the body's tissues. The development of disease is related to the amount of LCM virus carried, the size of the anti-LCM antibody response made and the interaction between virus and antibody. Those strains carrying the largest amount of LCM virus and anti-LCM antibody develop the earliest and most severe disease.

\footnotetext{
* This is publication No. 304 from the Department of Experimental Pathology, Scripps Clinic and Research Foundation, La Jolla, Calif.

¥ This research was supported by a United States Public Health Service Grant AI 07007 and Atomic Energy Commission Contract AT (04-3)-410.

§ Supported by United States Public Health Service Training Grant, GM683.
} 


\section{Materials and Methods}

Host

Mice.-Breeders for SWR/J, B10D2 old and new lines, AJAX, $\mathrm{AKR}$, and $\mathrm{C}_{3} \mathrm{H}$ inbred strains were obtained from Jackson Memorial Laboratories, Bar Harbor, Maine. NZB and NZB/W breeders were obtained from Laboratory Animal Center, Medical Research Council, Carshalton, Surrey, England. Breeding was performed in our laboratory. Adult Swiss Webster (SW) mice, 10-15 g, were obtained from a local breeder. Random testing of mice indicated they were free of LCM infection.

Virus Carrier State. -Newborn mice were inoculated either with $1000 \times$ LD50 $_{5}$ dose of virus prepared from infected isologous mouse brain or a $10 \%$ suspension of normal (noninfected) isologous brain within the first $\mathbf{1 5} \mathrm{hr}$ of life. Details of virus passage, inoculation procedure and development of LCM carrier state have been previously reported (17).

Virus

Source.-LCM virus used was mouse brain passage NIH Strain 7022 provided by Dr. Wallace Rowe of the National Institute of Allergy and Infectious Disease, Bethesda, Md. Methods of handling and diluting of virus for inoculation have been previously described (18).

Titration.-Virus titrations were carried out by intracerebral inoculation of six adult SW mice per serial 10 -fold dilutions of virus as previously reported (17). LD50 titration end points were calculated by the method of Reed and Muench (19).

\section{Gamma Globulin, Anti-LCM Antibody, and Complement in Carrier Mice}

Elution of Kidney Fixed $\gamma$-Globulin.-The sediment of washed kidney homogenate was suspended in $0.02 \mathrm{M}$ citrate buffer, $\mathrm{pH} 3.2,20 \mathrm{ml} / \mathrm{g}$ of kidney, and incubated at $37^{\circ} \mathrm{C}$ for 60 min with constant shaking. The suspension was cooled to $4^{\circ} \mathrm{C}$ and the molarity and $\mathrm{pH}$ corrected to $0.15 \mathrm{M}, \mathrm{pH} 7$ respectively, by the addition of $1 \mathrm{M} \mathrm{NaCl}$ and $1 \mathrm{MSH}_{2} \mathrm{KO}_{4}$. The kidneys eluted were as follows: $(a)$ six pairs of kidneys from both 3 and 6 month old $\mathrm{C}_{3} \mathrm{H}$ and SWR/J LCM carrier mice; (b) six pairs of kidneys from both 3 and 6 month old $\mathrm{C}_{3} \mathrm{H}$ and SWR/J control mice; (c) a pool of 25 pairs of kidneys from 2-3 month old SWR/J LCM carrier and control mice.

Detection of Anti-LCM Antibody.-The microcomplement fixation test, reported by Wasserman and Levine (20) employing $1.2 \mathrm{C}^{\prime} \mathrm{H}_{50}$ units of guinea pig $\mathrm{C}^{\prime}$, was used on renal eluates. LCM complement-fixing antigen was kindly provided by Dr. Hercules and Dr. Parker of Microbiological Associates, Washington, D. C.

Techniques for complement fixation and neutralizing tests for anti-LCM antibody in serum of LCM carrier mice have been previously reported (11).

In order to determine how much of the $\gamma$-globulin eluted from the kidneys was anti-LCM antibody, the $\gamma$-globulin in the eluates was quantitated before and after absorption with normal and LCM infected tissue cultures. Rhesus monkey kidney cultures were grown to a confluent monolayer and then infected with LCM virus. On the 7th day after infection with LCM virus, about $80 \%$ of cells contained LCM antigen by direct immunofluorescent technique and these cultures were used for absorptions. $10 \mathrm{mg}$ of protein by weight, eluted from a kidney pool of 2-3 months old SWR/J LCM carrier mice, was diluted in $2 \mathrm{ml}$ of medium 199, passed through a $0.2 \mu$ Millipore filter, and layered over LCM infected monkey kidney cell monolayer contained in a $20 \mathrm{~cm}^{2}$ bottle. The renal eluate was incubated sequentially in three LCM infected monkey kidney cell culture bottles for a period of $24 \mathrm{hr}$ per bottle. Controls consisted of LCM carrier renal eluates similarly absorbed on noninfected monkey kidney cultures. At the end of 3 days incubation, the treated eluates were collected from the culture bottle and 
spun at $700 \mathrm{~g}$ in an International centrifuge. The concentration of mouse $\gamma$-globulin in the supernatants were quantitated using radial immunodiffusion assay employing high titer rabbit anti-mouse $\gamma$-globulin diluted 1:160 in agar $(21,22)$.

Test for Antinuclear and Anti-Glomerular Basement Membrane Antibodies.-Pooled eluates from kidneys of LCM carrier mice in a concentration of $130 \mu \mathrm{g}$ of mouse $\gamma$-globulin $/ \mathrm{ml}$ were layered on acetone fixed normal mouse kidney sections for 30-min. Following two $10 \mathrm{~min}$ phosphate buffer saline washes, the sections were stained with rabbit anti-mouse $\gamma$-globulin conjugated with fluorescein isothiocyanate (FITC).

Elimination of Third Component of Guinea Pig Complement $\left(C^{\prime} 3\right)$ in LCM Carrier and Conirol Mice.-Purified guinea pig C'3 obtained through the courtesy of Dr. Manfred Mayer and Dr. Hyin Shin of Johns Hopkins was labeled with ${ }^{125}$ I (23). After labeling, 80-85\% of the $C^{\prime} 3$ was found to be unchanged in the electrophoretically faster, unconverted form when analyzed by immunoelectrophoresis under conditions described by Linscott and Cochrane (24). The labeled $C^{\prime} 3$ was found to be active in a hemolytic titration, with $E A C^{\prime} 1 a, 4,2 a$, performed by Dr. Neil Cooper.

Approximately $1 / 2 \mu \mathrm{C}$ of $\mathrm{C}^{\prime} 3^{-125} \mathrm{I}$ was inoculated intravenously into five SWR/J LCM carrier and five control mice. Experiments were run in duplicate. Whole body counts were determined in a well type $\mathrm{NaI}$ crystal scintillation counter within 5 min after injection of $\mathrm{C}^{\prime}{ }^{3-125} \mathrm{I}$ and repeated at intervals of $2-4 \mathrm{hr}$. The counts were corrected for coincidence and background. Previous experiments revealed that there was no difference in the elimination of labeled bovine serum albumin or rabbit $\gamma$-globulin between SWR/J LCM carriers and controls.

Fixation of Injected Guinea Pig $C^{\prime} 3$ in Glomeruli of SWR/J and B10D2 Old LCM Carrier Mice.-Fresh guinea pig serum was injected intravenously into five SWR/J and five B10D2 old LCM carrier and five control mice of each strain. Similarly, zymosan-treated guinea pig serum (24) was injected intravenously into five SWR/J and B10D2 old carrier mice. $6 \mathrm{hr}$ after injection, all animals were sacrificed. Frozen kidney sections were studied by direct immunoflorescent technique for the presence of guinea pig $\mathrm{C}^{\prime} 3$.

Determination of $L C M-\gamma-$ Globulin Complexes in the Circulation of LCM Carrier Mice.Pooled fresh sera from 2-3 month old LCM carrier mice were treated with either monospecific rabbit anti mouse $\gamma$-globulin or rabbit anti-mouse albumin. Three volumes of high titer hyperimmune antiserum were added to each volume of LCM carrier sera. The mixture was incubated at $37^{\circ} \mathrm{C}$ for $20 \mathrm{~min}$ and then left at $4^{\circ} \mathrm{C}$ for $4 \mathrm{hr}$. The resulting precipitate was removed by centrifugation, $700 \mathrm{~g} \times 20 \mathrm{~min}$. These steps were repeated until addition of specific antiserum caused no visible precipitate and the superantant was free of detectable mouse $\gamma$-globulin or albumin by immunoelectrophoresis and Ouchterlony techniques. The amount of infectious virus remaining was assayed by inoculating 10 -fold dilutions of the final supernatant intracerebrally into adult $\mathrm{SW}$ mice. Six mice were used per dilution and the $\mathrm{LD}_{50}$ was calculated by method of Reed and Muench (19). Sera from LCM carrier mice of SWR/J, B10D2, and AJAX strains were studied by this method. Also, as a control, stock LCM virus was mixed with normal mouse $\gamma$-globulin and studied similarly.

\section{Immunofluorescent-Histopathologic Techniques}

Fluorescent Antibody Studies.-Tissue blocks were snap-frozen in liquid nitrogen and sections $4 \mu$ thick were cut, fixed, and examined by the direct immunofluorescent technique as previously reported $(18,25)$. Rabbit anti-mouse $\gamma$-globulin, anti-mouse albumin, anti-mouse $C^{\prime} 3$, anti-guinea pig $\mathrm{C}^{\prime} 3$, anti-rat fibrinogen, and guinea pig anti-LCM monospecific antisera were used. Rabbits and guinea pigs were immunized with 0.5 to $1 \mathrm{mg}$ of antigen in complete Freund's adjuvant four to six times over a 4 month period. Details as to preparation of the antigens used and conjugation of $\gamma_{2}$-globulins from above antisera to FITC have been reported $(25,26)$. 
In addition, fluoresceinated guinea pig anti-LCM kindly supplied by Dr. R. Wilsnack of the Baltimore Biological Laboratories, Research Department, Baltimore, Md., was employed. Histology.-Formalin-fixed paraffin sections of tissue were stained by hematoxylin and eosin and periodic acid-Schiff (PAS) methods.

Pathologic Changes Associated with LCM Carrier State

LCM carrier and control mice of the various strains under study were examined for clinical and pathologic changes of an associated disease from 10 days to 24 months of age. Clinical study consisted of daily observations and monthly weights and urinary protein determinations. Weight was recorded to the nearest $0.1 \mathrm{~g}$. Proteinuria was determined by the sulfosalicylic acid method (27) on $24 \mathrm{hr}$ collections. Proteinuria over $5 \mathrm{mg} / 24 \mathrm{hr}$ was considered abnormal. Histopathologic evidence of chronic disease in LCM carriers included glomerulonephritis, focal hepatic necrosis, generalized lymphoid hyperplasia, and focal lymphoid infiltrations.

RESULTS

\section{LCM Carrier State}

1. Concentration of LCM Infectious Virus in Tissues of 2-3 Month Old Neonatally Infected LCM Carrier Mice.-Tissues from 4 LCM carrier mice of SWR/J $\mathrm{B} 10 \mathrm{D} 2, \mathrm{NZB}, \mathrm{AKR}$, and $\mathrm{C}_{3} \mathrm{H}$ strains showed wide interstrain variations in the concentration of infectious LCM virus (Table I). The SWR/J carriers had the highest concentration of infectious LCM virus, approximately 3 logs more than the $\mathrm{C}_{3} \mathrm{H}$ or $\mathrm{AKR}$ strains which had the least.

2. Immunofiuorescent Study of Neonatally Infected LCM Carrier Mice.Tissues from 10 male and 10 female 2-3 month old LCM carrier and control mice of SWR/J, B10D2, AJAX, AKR, NZB, NZB/W, and $\mathrm{C}_{3} \mathrm{H}$ strains were studied for distribution of LCM antigen, host $\gamma$-globulin, $C^{\prime} 3$, albumin, and fibrinogen by direct immunofluorescent technique (Table I). In addition, similar studies were performed on fewer LCM carrier and control mice sacrificed monthly from 10 days to 12 months of age and every 3 rd month thereafter. The LCM antigen was found in the cell cytoplasm in all tissues studied and appeared as fine to coarse particles which fluoresced apple green after staining with fluorescein-labeled anti-LCM antibody. The greatest concentration of LCM antigen occurred in brain, liver, and kidney. In contrast to the widespread distribution of viral antigen, there were only two sites of accumulation of plasma proteins: the glomeruli which contained $\gamma$-globulin and $\mathrm{C}^{\prime} 3$ and the regions of focal hepatic necrosis which contained all plasma proteins looked for.

Brain: Viral antigen was found irregularly distributed in neurons of the cortex, thalamus, hippocampus, and cerebellum. Uncommonly, cells of the choroid plexus and arterial endothelium contained LCM antigen. No evidence of $\gamma$-globulin, $\mathrm{C}^{\prime} 3$, fibrinogen, or albumin deposits was found in CNS.

Liver: In general, the LCM antigen occurred in clumps of otherwise normalappearing parenchymal cells. These cell clumps were scattered and not confined to any specific architectural area of liver lobule. Infrequently, LCM antigen was seen in Kupffer cells, arterial endothelium, or biliary duct epithelium. 
The foci of hepatic necrosis, one of the characteristic lesions of this disease, invariably contained LCM antigen, $\gamma$-globulin, $C^{\prime} 3$, fibrinogen, and albumin.

Kidney: Viral antigen was observed in the convoluted tubules, connective tissue, arterial endothelium, and glomeruli. The distribution of LCM antigen in the glomeruli was heaviest in the mesangial areas but also occurred in the peripheral walls of capillaries. In addition, both $\gamma$-globulin and $\mathrm{C}^{\prime} 3$ were deposited in the glomeruli along the basement membranes of capillaries and in

TABLE I

Infectivity Titers and Immunofluorescent Staining in 2-3 Month Old LCM Carrier Mice

\begin{tabular}{|c|c|c|c|c|c|c|c|c|c|}
\hline \multirow{2}{*}{ Strains } & \multicolumn{2}{|c|}{ Brain } & \multicolumn{2}{|c|}{ Liver } & \multicolumn{4}{|c|}{ Kidney } & \multirow{2}{*}{$\begin{array}{c}\begin{array}{c}\text { Other } \\
\text { organs" }\end{array} \\
\text { LCM Ag }\end{array}$} \\
\hline & Titer & $\underset{\mathrm{Ag} \delta}{\mathrm{LCM}}$ & Titer & $\underset{\mathrm{Ag}}{\mathbf{L C M}}$ & Titer & $\underset{\mathrm{Ag}}{\mathrm{LCM}}$ & $\gamma \mathrm{G} \|$ & $C^{\prime} 3 \|$ & \\
\hline SWR/J & 4.8 & $+t$ & 5.4 & + & 5.4 & + & $+t$ & ++ & \pm \\
\hline B10D2 new & 3.4 & ++ & 3.4 & + & 3.8 & + & ++ & ++ & \pm \\
\hline B10D2 old & 3.1 & ++ & 3.4 & + & 3.6 & + & ++ & ++ & \pm \\
\hline NZB & 2.9 & ++ & 3.0 & + & 3.4 & + & ++ & ++ & \pm \\
\hline $\mathrm{NZB} / \mathrm{W}$ & - & ++ & - & + & - & + & ++ & $+t$ & \pm \\
\hline AJAX & - & ++ & - & + & - & + & + & + & \pm \\
\hline AKR & 1.8 & ++ & 2.0 & + & 2.0 & + & \pm & \pm & \pm \\
\hline $\mathrm{C}_{3} \mathrm{H}$ & 1.7 & $+t$ & 1.6 & + & 1.9 & + & \pm & \pm & \pm \\
\hline
\end{tabular}

* Heart, skeletal muscle, lung, intestinal tract, spleen, and lymph node.

¥ Reciprocal of log dilution giving a 50\% lethal end point per $0.03 \mathrm{ml}$ intracerebral inoculum. Number is the mean value of the ID50 end points obtained with organs from four individual mice.

$\$$ Degree of involvement as determined by direct immunofluorescence: 0 , negative result; \pm , less than $2 \%$ cells involved;,$+ 2-10 \%$ cells involved; ++ , greater than $10 \%$ cells involved.

|| Degree of glomerular involvement as determined by direct immunofluorescence: 0 , no globulin deposit; \pm , minimal globulin deposit in general limited to mesangial area; + , moderate globulin deposit in mesangial and peripheral loop area; ++ , marked globulin deposits in mesangial and peripheral loop areas. Neither $\gamma$-globulin nor $C^{\prime} 3$ was found deposited in any other tissues studied except in areas of focal necrosis in the liver.

the mesangia (Fig. 2). There was no corresponding mouse albumin or fibrinogen deposition. A marked difference among various strains of LCM carrier mice as to amount of glomerular-bound $\boldsymbol{\gamma}$-globulin was noted, with most present in SWR/J and least in $\mathrm{C}_{3} \mathrm{H}$ and AKR LCM carriers (Fig. 3). This was of interest since 3 month old SWR/J LCM carriers had been shown to contain about 3 logs more infectious virus than 3 month old $\mathrm{C}_{3} \mathrm{H}$ LCM carriers (Table I). Control mice inoculated with isologous normal brain at birth had neither significant $\boldsymbol{\gamma}$-globulin nor $\mathrm{C}^{\prime} 3$ deposits in their glomeruli.

3. Nature of the $\gamma$-Globulin Deposits in the Renal Glomeruli.-The $\gamma$-globulin 
TABLE II

Anti-LCM Antibody Eluted from Kidneys of LCM Carrier Mice*

\begin{tabular}{|c|c|c|c|c|c|}
\hline \multirow{3}{*}{ Mouse No. } & \multicolumn{5}{|c|}{ Dilution of renal eluate } \\
\hline & $1: 4$ & 1:10 & $1: 50$ & $1: 250$ & $1: 500$ \\
\hline & \multicolumn{5}{|c|}{ Hemolysis-OD readings $413 \mathrm{~m} \mu$} \\
\hline \multicolumn{6}{|c|}{$S W R / J-3$ months old } \\
\hline $\begin{array}{l}1 \\
2 \\
3 \\
4 \\
5 \\
6\end{array}$ & $\begin{array}{l}0.06 \\
0.09 \\
0.22 \\
0.14 \\
0.08 \\
0.22\end{array}$ & $\begin{array}{l}0.30 \\
0.36 \\
0.34 \\
0.28 \\
0.24 \\
0.35\end{array}$ & $\begin{array}{l}0.35 \\
0.44 \\
0.46 \\
0.36 \\
0.40 \\
0.48\end{array}$ & $\begin{array}{l}0.48 \\
0.53 \\
0.58 \\
0.54 \\
0.54 \\
0.56\end{array}$ & $\begin{array}{l}0.58 \\
0.57 \\
0.57 \\
0.57 \\
0.56 \\
0.54\end{array}$ \\
\hline \multicolumn{6}{|c|}{$S W R / J-6$ months old } \\
\hline $\begin{array}{l}1 \\
2 \\
3 \\
4 \\
5 \\
6\end{array}$ & $\begin{array}{l}0.08 \\
0.07 \\
0.12 \\
0.13 \\
0.05 \\
0.10\end{array}$ & $\begin{array}{l}0.17 \\
0.20 \\
0.22 \\
0.38 \\
0.09 \\
0.24\end{array}$ & $\begin{array}{l}0.32 \\
0.34 \\
0.34 \\
0.47 \\
0.28 \\
0.36\end{array}$ & $\begin{array}{l}0.38 \\
0.52 \\
0.41 \\
0.49 \\
0.40 \\
0.44\end{array}$ & $\begin{array}{l}0.51 \\
0.54 \\
0.53 \\
0.56 \\
0.54 \\
0.57\end{array}$ \\
\hline \multicolumn{6}{|c|}{$C_{3} H-3$ months old } \\
\hline $\begin{array}{l}1 \\
2 \\
3 \\
4 \\
5 \\
6\end{array}$ & $\begin{array}{l}0.16 \\
0.22 \\
0.38 \\
0.14 \\
0.11 \\
0.18\end{array}$ & $\begin{array}{l}0.52 \\
0.50 \\
0.55 \\
0.36 \\
0.40 \\
0.37\end{array}$ & $\begin{array}{l}0.56 \\
0.56 \\
0.58 \\
0.56 \\
0.56 \\
0.55\end{array}$ & & \\
\hline \multicolumn{6}{|c|}{$\mathrm{C}_{3} \mathrm{H}-6$ months old } \\
\hline $\begin{array}{l}1 \\
2 \\
3 \\
4 \\
5 \\
6\end{array}$ & $\begin{array}{l}0.14 \\
0.26 \\
0.27 \\
0.15 \\
0.12 \\
0.18\end{array}$ & $\begin{array}{l}0.38 \\
0.36 \\
0.42 \\
0.40 \\
0.39 \\
0.41\end{array}$ & $\begin{array}{l}0.51 \\
0.44 \\
0.49 \\
0.54 \\
0.53 \\
0.58\end{array}$ & $\begin{array}{l}0.56 \\
0.57 \\
0.58 \\
0.56 \\
0.55 \\
0.56\end{array}$ & \\
\hline \multicolumn{6}{|c|}{ Controls } \\
\hline $\begin{array}{l}\text { LCM Ag } \\
\text { SWR/J eluate } \\
3 \text { months } \\
6 \text { months } \\
\mathrm{C}_{3} \mathrm{H} \text { eluate } \\
3 \text { months } \\
6 \text { months } \\
\mathrm{C}^{\prime}\end{array}$ & $\begin{array}{l}0.54 \\
0.56 \\
0.58 \\
\\
0.54 \\
0.58 \\
0.55\end{array}$ & & & & \\
\hline
\end{tabular}

* Microcomplement-fixation assay (20). $1.2 \mathrm{C}^{\prime} \mathrm{H}_{50}$ units were used in the assay. The antigen was specific LCM complement-fixing antigen. Any reading below 0.41 indicates $25 \%$ or more complement fixation and is considered significant. 
eluted from the glomeruli, when assayed in a microcomplement fixation test in the presence of added specific LCM antigen, was shown to contain antibody to LCM virus (11). Experiments were designed to determine whether the amount of anti-LCM antibody deposited in the kidneys of LCM carrier mice increased with time and whether the difference in kidney bound $\gamma$-globulin seen in $\mathrm{C}_{8} \mathrm{H}$ and SWR/J LCM carriers was related to the difference in amount of antiLCM antibody in the deposits. Table II indicates that the amounts of antiLCM antibody deposited in the kidneys of carrier mice of SWR/J and $\mathrm{C}_{3} \mathrm{H}$

TABLE III

Quantitation by Radial Immunodiffusion of LCM Specific $\gamma$-Globulin in the Renal Eluates of 2 Month Old SWR/J Carriers

\begin{tabular}{l|c|c}
\hline \multirow{2}{*}{ Sample } & \multicolumn{2}{|c}{ Ring diameter } \\
\cline { 2 - 3 } & $24 \mathrm{hr}$ & $48 \mathrm{hr}$ \\
\hline Standard concentrations of mouse $\gamma \mathrm{G}, \mu \mathrm{g} / \mathrm{ml}$ & $m \mathrm{~mm}$ \\
500 & 9 & 12 \\
250 & 7 & 9 \\
125 & 4 & 6 \\
62.5 & 0 & 0 \\
& & \\
Renal Eluate & & \\
Preabsorption & 7 & 9 \\
No. 1 & 7 & 8.5 \\
No. 2 & 7 & 8 \\
Postabsorption (noninfected MKC) & & \\
No. 1 & 6.5 & 9 \\
No. 2 & 5 & 6 \\
Postabsorption (LCM infected MKC)* & 4 & 6 \\
No. 1 & & \\
No. 2 & & \\
\hline
\end{tabular}

* Absorption by noninfected or 7 day LCM infected monolayers of monkey kidney cells grown in $20 \mathrm{~cm}^{2}$ bottles. Three bottles used per assay and $24 \mathrm{hr}$ absorption per bottle.

strains increased as the mice aged. In addition, more anti-LCM antibody was found in the kidneys of SWR/J than in $\mathrm{C}_{3} \mathrm{H}$ LCM carrier mice at both 3 and 6 months of age. Neither anti-glomerular basement membrane antibody nor antinuclear antibody was detected in the renal eluates of LCM carrier mice.

The concentration of mouse $\gamma$-globulin present in the renal eluate of 2 month old SWR/J carriers was found to be approximately $250 \mu \mathrm{g} / \mathrm{ml}$ or about $4-5 \%$ of the total protein eluted. Addition of the renal eluate to LCM infected monkey kidney cells resulted in the absorption of $130 \mu \mathrm{g}$ or approximately $1 / 2$ of the eluted $\gamma$-globulin (Table III). No significant absorption of $\gamma$-globulin was noted when the renal eluate was incubated with noninfected monkey kidney cells. 
4. Time of Appearance of Glomerular Bound $\gamma$-Globulin in the Kidneys of $S W R / J$ LCM Carriers.-Renal tissue from ten 10 day old and 15 21-day-old neonatally infected SWR/J carriers was studied for the presence of mouse $\gamma$ globulin by direct immunofluorescent technique. Faint mesangial deposition of $\gamma$-globulin was found in the glomeruli of only one 10 day old SWR/J carrier, while a significant deposition of $\gamma$-globulin in both mesangia and peripheral capillary walls was found in the glomeruli of 14 of 15 21-day-old SWR/J LCM carriers.

5. Elimination of Guinea Pig $C^{\prime} 3$ in LCM Carrier and Control SWR/J Mice.Elimination of the $\mathrm{C}^{\prime}{ }^{3}{ }^{125} \mathrm{I}$ label from SWR/J carrier and control mice is illustrated in Fig. 1. The rapid elimination in the first $5 \mathrm{hr}$ in both groups is probably, in part, due to the rapid removal of the inactive contaminant $\left(\mathrm{C}^{\prime} 3 \mathrm{i}^{125} \mathrm{I}\right)$. From the 5 th to 15 th $\mathrm{hr}$, the rate of elimination of label from LCM carriers was rapid with a half-life of $4 \mathrm{hr}$ compared to $12 \mathrm{hr}$ for controls.

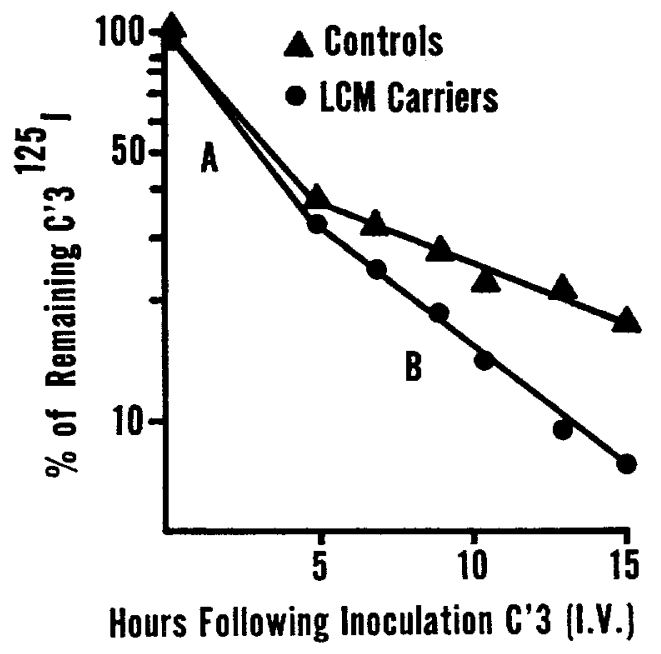

FIc. 1. Elimination of guinea pig $\mathrm{C}^{\prime} 3$ in SWR/J LCM carrier and control mice. The $A$ part of the curve represents the rapid elimination of the labeled inactive contaminant ( $C^{\prime} 3 \mathrm{i} \mathrm{I}^{*}$ ) and the half-life is $2 \frac{1}{2}-2 \frac{2}{3} \mathrm{hr}$ in both LCM carriers and control mice. The $B$ portion of the curve represents the rate of elimination of active $\mathrm{C}^{\prime} 3 \mathrm{I}^{*}$ in which the half-life of label in LCM carriers is $4 \mathrm{hr}$ compared to $12 \mathrm{hr}$ in controls. Each point on the graph represents the average value for five mice.

6. Fixation of Guinea Pig $C^{\prime} 3$ in the Glomeruli of LCM Carrier Mice-By direct immunofluorescent technique, guinea pig $\mathrm{C}^{\prime} 3$ was detected in both mesangia and capillary walls of the glomeruli of LCM carrier mice of SWR/J and B10D2 old strains $6 \mathrm{hr}$ after the intravenous injection of fresh guinea pig serum. After the injection of fresh guinea pig serum into control mice, or zymosan-treated 
guinea pig serum into SWR/J or B10D2 old LCM carriers, guinea pig $\mathrm{C}^{\prime} 3$ was not detectable in peripheral capillary walls of glomeruli.

7. Circulating Antigen-Antibody Complexes in 2-3 Month Old LCM Carrier Mice.-Finding of LCM antigen, anti-LCM antibody, and complement in the glomeruli of LCM carrier mice suggested that these deposits represented trapped circulating virus-antibody complexes. If circulating virus- $\gamma$-globulin complexes were present, the removal of host $\gamma$-globulin should result in a lowering of the $\mathrm{LD}_{50}$ end point when the treated sera were titered in susceptible mice. LCM carrier sera lost approximately 3 logs of infectivity after removal of $\gamma$ globulin with rabbit anti-mouse $\gamma$-globulin, while no loss followed similar treatment with anti-mouse albumin (Table IV). Mixtures of stock LCM virus and normal mouse $\boldsymbol{\gamma}$-globulin did not result in formation of precipitable LCM- $\gamma$ globulin complexes indicating the immunologic specificity of the complexes found in the sera of carrier mice.

TABLE IV

Virus- $\gamma$-Globulin Complexes in Sera of 2-3 Month Old LCM Carrier SWR/J Mice*

\begin{tabular}{l|l|l|l|l|l|r}
\hline & \multicolumn{5}{|c|}{ Dilution of treated supernates } & LDı0 \\
\cline { 2 - 6 } Treatment of infectious sera & $2 \times 10^{-1}$ & $10^{-2}$ & $10^{-3}$ & $10^{-4}$ & $10^{-8}$ & \\
\hline Normal rabbit serum & $6 / 6 \ddagger$ & $6 / 6$ & $6 / 6$ & $2 / 6$ & $0 / 6$ & $2 \times 10^{-3.7}$ \\
Anti-mouse $\gamma$-globulin & $2 / 6$ & $0 / 6$ & $0 / 6$ & $0 / 6$ & $0 / 6$ & $<2 \times 10^{-1}$ \\
Anti-mouse albumin & $6 / 6$ & $6 / 6$ & $5 / 6$ & $1 / 6$ & $0 / 6$ & $2 \times 10^{-3.5}$ \\
\hline
\end{tabular}

* Similar results have been observed in B10D2 old and AJAX LCM carrier mice.

$\ddagger$ Number of deaths per total number of SW mice inoculated intracerebrally with treated supernatants.

Chronic Disease Associated with the LCM Carrier State in Various Murine Strains

In certain murine strains a disease is associated with the LCM carrier state (Table V). This disease clinically is characterized by increased proteinuria in $\mathrm{NZB}, \mathrm{SWR} / \mathrm{J}, \mathrm{NZB} / \mathrm{W}$ strains, and an increased early mortality in NZB and NZB/W mice. Except for a terminal loss of weight in the NZB and NZB/W mice, no significant difference in weight was observed between LCM carrier or control mice in any of the strains studied.

Histopathologically, the cardinal manifestations of chronic disease occurred in the kidney and liver. In the kidney, the earliest manifestations of disease were endothelial and mesangial proliferation in capillaries of renal glomeruli. Later, varying gradations of basement membrane thickening, intracapillary hyalinization, and capillary occlusion developed (Fig. 4). In the liver, scattered areas of focal necrosis with mixed inflammatory infiltrates began to appear as early as 
2 months in SWR/J carriers and were numerous in all strains observed except $\mathrm{C}_{3} \mathrm{H}$ by $1 \mathrm{yr}$ (Fig. 5). Location of the focal areas of necrosis had no detectable relationship to hepatic architecture. Appearing with the liver and kidney lesions were excessive lymphoid proliferations and mononuclear interstitial infiltrates, predominantly in liver, kidney, lungs and, to a lesser extent, in pancreas, adrenal, omental fat, heart, spleen, thymus and, rarely, brain (Fig. 6).

Histologic evidence of disease in kidney and liver occurred as early as 2 months of age in SWR/J but has not been observed over a 24 month period in $\mathrm{C}_{3} \mathrm{H}$ LCM carriers. The disease is severe in NZB and NZB/W mice. By 5 months of age, $100 \%$ of NZB female LCM carriets demonstrated proteinuria

TABLE V

Incidence of Chronic Disease in LCM Carrier Mice*

\begin{tabular}{l|r|r|r|r|r}
\hline \multirow{2}{*}{ Strain } & \multicolumn{5}{|c}{ Months } \\
\cline { 2 - 6 } & 3 & 9 & 12 & 18 & 24 \\
\hline & $\%$ & $\%$ & $\%$ & $\%$ & $\%$ \\
SWR/J & 100 & 100 & 100 & 100 & 100 \\
B10D2 new & 0 & 40 & 90 & 90 & 90 \\
B10D2 old & 0 & 30 & 90 & 90 & 90 \\
NZB & 60 & $100 \ddagger$ & & & \\
NZB/W & 40 & $-\$$ & - & - & - \\
AJAX & 0 & 20 & - & - & - \\
C 3 H & 0 & 0 & 0 & 0 & 0 \\
\hline
\end{tabular}

* Chronic disease is defined as histologic evidence of either renal glomerular injury or focal necrosis in the liver. These usually occur together and are associated with marked lymphoid proliferation and mononuclear interstitial infiltration in several of the body's tissues. (See Materials and Methods).

† Fatal disease.

$\$-$, Not sufficient observations at these time periods.

over $5 \mathrm{mg} / 24 \mathrm{hr}$ and by 6 months 20 of 20 female LCM carriers had died, apparently of nephritis. By 9 months, over $90 \%$ of male NZB LCM carrier mice also were dead of nephritis. Preliminary studies with Dr. P. H. Lambert suggest both an earlier appearance and an increase in titer of antinuclear antibody in the serum of NZB and NZB/W LCM carrier mice compared to NZB or NZB/W controls.

\section{DISCUSSION}

Mice infected at birth with LCM virus are capable of making an anti-LCM antibody response throughout most of their lives. This antibody cannot be detected free in the circulation because of an excess of antigen or virus, but the presence of antibody can be inferred from the circulating $\gamma$-globulin-virus com- 
plexes. Anti-LCM antibody can be dissociated from antibody-virus complexes deposited in the kidneys and then measured directly. The earlier failure to detect circulating, neutralizing, or complement-fixing anti-LCM antibodies in LCM carriers suggested that these mice were immunologically tolerant to the virus to which they had been exposed early in life $(7-10,16,28)$. However, it now is clear that an early exposure to LCM virus does not induce tolerance even if persistent viral infection in the host maintains continuous viral excess in tissues and blood. One might well question whether virus infection under any conditions can induce immunologic tolerance. With the possible exception of some tumor viruses, various in utero or early life, experimental or natural exposures to virus, including human in utero infections with rubella and cytomegalovirus, have not resulted in tolerance.

It is not possible to be sure whether or not early infection with LCM or other viruses induces an immunological hyporesponsiveness since an accurate measure of the total antibody in the presence of an excess of viral antigen is impossible. Also, it is difficult to select a standard immunoresponse by which to judge the immunocompetence of the neonatally infected host. However, that the response of the LCM carriers is long lasting, even perhaps life long, is indicated by the increasing accumulation of $\gamma$-globulin and anti-LCM antibodies in the kidney with age.

The size and time of initial detection of the anti-LCM response in LCM carriers varies among different strains of mice. In the strains carrying the greatest amount of virus, the antibody response appears to be the largest while those strains with the least virus have the smallest amount of antibody. The time of initial detection of the anti-LCM antibody is probably a function of the size of the response and therefore is earliest in those strains making the largest responses. In SWR/J carrier mice, which make the largest anti-LCM response, significant accumulation of $\gamma$-globulin is present in the glomeruli at $3 \mathrm{wk}$ of age. This observation is only presumptive evidence for anti-LCM antibody but it fits with the detection of circulating $\gamma$-globulin-virus complexes and the presence of dissociable $\mathrm{C}^{\prime}$-fixing anti-LCM antibodies in the kidneys at $8 \mathrm{wk}$ of age. While some of the anti-LCM antibody present in nursing carriers possibly might be derived from the mother's milk, since the mother becomes infected by contact with her offspring and makes a response to the LCM virus, the uninterrupted increase in all measures of anti-LCM antibody in the carriers postweaning strongly suggest that most, if not all, antibody present in the carriers is made by them.

There is considerable difference in the amount of virus present in LCM carriers of different murine strains. While all strains showed a comparable widespread distribution of viral antigen among the various tissues, there was a better than 1000-fold difference between the amount of infectious virus carried by the most susceptible SWR/J strain and the most resistant $\mathrm{C}_{3} \mathrm{H}$ strain. If immuno- 
logic tolerance were to be induced by the LCM virus in the carrier state one might expect the strain with the greatest amount of virus to be the most likely to be tolerant. In fact the opposite is the case and, while no strain was found to be tolerant, the strain with the most virus had the most detectable anti-LCM antibody. It is of interest that the amount of virus in the carriers of various strains correlated well with the susceptibility of adults of those strains to lethal effects of inoculation with LCM virus, i.e., the more virus in the carriers of a strain the more suceptible were adults of that strain to infection (17).

LCM carrier mice of several strains developed a characteristic disease consisting of chronic glomerulonephritis, focal hepatic necrosis, and generalized proliferation of lymphoid tissues with widespread focal interstitial lymphoid infiltrations. In view of the heavy proteinuria and advanced destruction of renal parenchyma, the renal lesion was in all likelihood the fatal component of the disease. The focal hepatic necroses varied in size involving from only a few to nearly 100 liver cells as seen on routine histologic sections but never became large, confluent, or appeared numerous enough to cause death. The hyperplastic and infiltrative changes in the lymphoid tissue were not associated with detectable tissue injury but rather appeared to be a proliferative response to antigenic stimulation.

The severity and time of onset of the disease associated with the LCM carrier state varied greatly from strain to strain. Those strains with the greatest amount of virus and the most antibody developed the earliest and most severe disease while the $\mathrm{C}_{3} \mathrm{H}$ strain with least virus and antibody had no detectable disease during a 2 yr observation period. The most susceptible strain, the SWR/J, had $\gamma$-globulin accumulations in the glomeruli detectable at $3 \mathrm{wk}$ of age and had histologically evident kidney, liver, and lymphoid disease by 2 months of age. In view of this early onset of disease in the more susceptible strains of mice the terms "late life" or "slow viral" disease are not accurate $(29,30)$. Since the disease is chronic and progressive regardless of when it begins, we have chosen to refer to it as chronic LCM disease. The finding of chronic LCM disease with varying severity in different strains of mice is in agreement with observations of other workers. Hotchin $(12,14)$, who described a similar disease, worked with a Swiss albino herd-bred (NYLAR-A) strain which is probably closely related to the inbred Swiss albino SWR/J strain. Volkert (16), who did not observe disease in LCM carriers, worked with $\mathrm{C}_{3} \mathrm{H}$ and AKR strains. Our observations have not been expanded past early life for the AKR strain because of its high incidence of leukemia; however, the relatively low amounts of LCM virus carried by $A K R$ mice suggests that this strain, like $\mathrm{C}_{3} \mathrm{H}$, would be resistant to development of disease.

Some aspects of pathogenesis of chronic LCM disease seem reasonably clear while others are not yet understood. On the basis of in vivo observations of the widespread distribution of LCM virus and the apparent lack of associated 
cellular injury, plus the lack of cytopathogenicity of LCM virus carried in a variety of cultured cells, it seems likely that the LCM virus itself causes little serious injury to cells which it infects. If this is true, the renal and hepatic injury resulting from persistent LCM virus infection must be caused by more than the mere presence of virus. This is similar to the situation in adult mice inoculated with LCM virus in which acute fatal disease did not result from infection alone but occurred only in infected animals capable of an immune response. Immunosuppression prior to infection prevented acute disease (3135). Thus, the interaction of the host immune response with the infecting agent appeared to be the essential pathogenetic event. Just so, in the chronic LCM disease, the interaction of the host's immune response and the LCM virus appears to be involved. If this immunologic reaction is the essential element of chronic LCM disease, then this disease could develop in any animal chronically infected with LCM and need not be restricted to the experimental neonatal infections reported here. An example might be the glomerulonephritis reported by Hirsch et al (36) in young thymectomized and LCM infected mice.

The glomerulonephritis of chronic LCM disease appears to have an immune complex pathogenesis, i.e., circulating virus-antibody complexes are trapped in the glomerular filter along with $\mathrm{C}^{\prime}$ and serve as a phlogogenic stimulus-causing disease. That circulating complexes of quite nontoxic antigens and antibody will become trapped in glomeruli and cause glomerulonephritis has been clearly demonstrated in a number of situations (37-39). In the LCM carrier, the specificity of the process by which complexes accumulate in the glomeruli is indicated by the fact that $50 \%$ of the $\gamma$-globulin eluted from the kidneys reacted with LCM antigen. In view of the conditions of the elution, it is likely that more than $50 \%$ of the $\gamma$-globulin fixed in the kidneys was anti-LCM antibody. Further, the demonstration of: (a) circulating virus- $\boldsymbol{\gamma}$-globulin complexes, $(b)$ viral antigen, $\gamma$-globulin, and $\mathrm{C}^{\prime}$ deposited along glomerular capillary basement membranes in a granular to lumpy pattern, $(c)$ virus and $\mathrm{C}^{\prime}$-fixing anti-viral antibody in the kidney, and $(d) \mathrm{C}^{\prime}$ fixation in vivo to the glomerular capillary walls all are in complete agreement with a LCM antigen-antibody complex pathogenesis for this nephritis. Thus, while the virus is an essential component in the pathogenesis, the nephritis does not appear to be virus induced in the sense of a direct cytotoxic action of the virus per se. Rather, the virus acts as a foreign serum protein does in serum sickness or DNA in lupus erythematosus, merely as the antigenic part of an antigen-antibody complex which actually exerts its phlogogenic stimulus by virtue of the structure of the antibody not the antigen.

The pathogeneses of the focal hepatic necrosis and lymphoid reactions are less clear. For the hepatic injury, several immunologic possibilities exist. First, large amounts of circulating antigen-antibody complexes can cause focal hepatic necrosis (40). In such situations the complexes may be seen lodged in hepatic 
sinusoids. Whether the hepatic injury in this situation results from compromised blood flow or from the presence of deposits of phlogogenic material or both is not known. Second, the interaction of LCM antigen or LCM induced neoantigen in hepatic cells with circulating antibody might cause injury to the cells. In vitro support for this concept has been obtained by Koprowski using tissue cultures infected with rabies virus (41) and by us using mouse embryo tissue cultures infected with LCM virus. In both cases the virus itself showed no cytopathogenic effect but when specific anti-viral antibody and $\mathrm{C}^{\prime}$ were added to the media death of infected cells occurred. Whether either or both of these two mechanisms operates in chronic LCM disease remains to be established but they are certainly likely possibilities. The nature and significance of the lymphoid hyperplasia and interstitial infiltrations are more obscure but these alterations appear similar to those sometimes seen in animals hyperimmunized to protein antigens and may merely be the result of long standing antigenic stimulation.

It appears likely that some of the characteristics of chronic LCM infection may be found in other persistent viral infections with high viremias. Preliminary studies in our laboratory have shown deposits of host $\gamma$-globulin and $\mathrm{C}^{\prime} 3$ in the glomeruli of mice with scrapie, lactic dehydrogenase, and leukemic viral infections, accompanied by glomerulonephritis in the latter two. If the parallel is complete, specific antiviral antibody should be obtainable from the glomeruli of mice with these infections.

\section{SUMMARY}

Mice infected shortly after birth with lymphocytic choriomeningitis (LCM) virus are not immunologically tolerant, although they carry the virus throughout life. These LCM carrier mice make anti-LCM antibody, which apparently complexes with viral antigen in the circulation and these complexes accumulate in the glomeruli.

LCM carrier mice of different strains vary significantly as to concentration of detectable infectious virus in their tissue, amount and time of appearance of anti-LCM antibody, and development of an associated chronic disease. The chronic disease consists primarily of glomerulonephritis, focal hepatic necrosis, and disseminated lymphoid infiltrations. LCM carriers of the SWR/J strain contain high tissue concentrations of virus, considerable anti-LCM antibody detectable in the glomeruli by $3 \mathrm{wk}$ to 2 months of age and develop chronic disease within the first 2-3 months of life. In contrast, $\mathrm{C}_{3} \mathrm{H}$ strain LCM carriers contain $1 / 1000$ as much infectious virus, less detectable anti-LCM antibody, and have not, over a 24 month observation period, developed any detectable disease. B10D2 old and new carrier mice with intermediate amounts of virus develop chronic disease during the latter half of the first year of life.

The pathogenesis of the glomerulonephritis of chronic LCM disease is ap- 
parently related to the formation of circulating virus-antibody complexes which are trapped in the glomerular filter. There is no evidence for direct glomerular injury by the virus nor for any autoimmune response by the host.

We thank Antoinette Tishon for her capable technical assistance.

\section{BIBLIOGRAPHY}

1. Traub, E. 1935. A filterable virus recovered from white mice. Science. 81:298.

2. Traub, E. 1935. A filterable virus from white mice. J. Immunol. 29:69.

3. Traub, E. 1936. The epidemiology of lymphocytic choriomeningitis in white mice. J. Exp. Med. 64:183.

4. Traub, E. 1936. Persistence of lymphocytic choriomeningitis virus in immune animals and its relation to immunity. J. Exp. Med. 63:847.

5. Traub, E. 1938. Factors influencing the persistence of choriomeningitis virus in the blood of mice after clinical recovery. J. Exp. Med. 68:229.

6. Traub, E. 1939. Epidemiology of the lymphocytic choriomeningitis in a mouse stock observed for four years. J. Exp. Med. 69:801.

7. Hotchin, J., and M. Cinits. 1958. Lymphocytic choriomeningitis infection of mice as a model for the study of latent virus infection. Can. J. Microbiol. 4:149.

8. Traub, E. 1960. Über die immunologioche Toleranz bei der lymphocytären Choriomeningitis der Mäuse. Zentr. Bakt. Orig. 177:472.

9. Volkert, M., and L. Hannover. 1964. Studies on immunological tolerance to LCM virus. 3. Duration and maximal effect of adoptive immunization of virus carriers. Acta Path. Microbiol. Scand. 60:577.

10. Burnet, F., and F. Fenner. 1949. The Production of Antibodies. Macmillan and Co. Ltd., Melbourne. 2nd edition. 104.

11. Oldstone, M., and F. Dixon. 1967. Lymphocytic choriomeningitis: production of antibody by "tolerant" infected mice. Science. 158:1193.

12. Hotchin, J. 1962. The biology of lymphocytic choriomeningitis infection: virusinduced autoimmune disease. Cold Spring Harbor Symp. Quant. Biol. 27:479.

13. Hotchin, J., and D. Collins. 1964. Glomerulonephritis and late onset disease of mice following neonatal virus infection. Nature. 203:1357.

14. Baker, F., and J. Hotchin. 1967. Slow virus kidney disease of mice. Science. 158: 502.

15. Mims, C. 1966. Immunofluorescence study of the carrier state and mechanism of vertical transmission in lymphocytic choriomeningitis viral infection in mice. J. Pathol. Bacteriol. 91:395.

16. Volkert, M. 1964. Studies on immunological tolerance to LCM virus. In Perspectives in Virology. V. M. Pollard, Editor. Harper and Row, New York. 4:269.

17. Oldstone, M., and F. Dixon. 1968. Susceptibility of different mouse strains to lymphocytic choriomeningitis virus. J. Immunol. 100:355.

18. Oldstone, M., and F. Dixon. 1968. Direct immunofluorescent tissue culture assay for lymphocytic choriomeningitis virus. J. Immunol. 100:1135.

19. Reed, L., and H. Muench. 1938. A simple method of estimating fifty percent endpoints. Amer. J. Hyg. $27: 493$.

20. Wasserman, E., and L. Levine. 1961. Quantitative micro-complement fixation 
and its use in the study of antigenic structure by specific antigen-antibody inhibition. J. Immunol. 87:290.

21. Mancini, G., A. Carbonara, and J. Heremans. 1965. Immunochemical quantitation of antigens by single radial immunodiffusion. Immunochemistry. 2:235.

22. Fahey, J., and E. McKelvay. 1965. Quantitative determination of serum immunoglobulins in antibody-agar plates. $J$. Immunol. 94:84.

23. McConahey, P., and F. Dixon. 1966. A method of trace iodination of proteins for immunologic studies. Int. Arch. Allergy Appl. Immunol. 29:185.

24. Linscott, W, and C. Cochrane. 1964. Guinea pig $\beta_{1}$ C-globulin: Its relationship to the third component of complement and its alteration following interaction with immune complexes. J. Immunol. 93:972.

25. Oldstone, M., and F. Dixon. 1968. Immunohistochemical study of allergic encephalomyelitis. Amer. J. Pathol. 62:251.

26. Unanue, E., and F. Dixon. 1964. Experimental glomerulonephritis. IV. Participation of complement in nephrotoxic nephritis. J. Exp. Med. 119:965.

27. Kingsbury, F., C. Clark, G. Williams, and A. Post. 1926. Rapid determination of albumin in urine. J. Lab. Clin. Med. 11:981.

28. Hotchin, J. 1965. Chronic disease following lymphocytic choriomeningitis virus inoculation and possible mechanisms of slow virus pathogenesis. In Slow, Latent and Temperate Virus Infections. National Institute of Neurological Diseases and Blindness. Monogr., No. 2. U.S. Public Health Serv. Publ. 1378:341.

29. Sigurdsson, B. 1954. Rida, a chronic encephalitis of sheep with general remarks on infections which develop slowly, and some of their special characteristics. Brit. Vet. J. 110:341.

30. Gibbs, C., Jr., and D. Gajdusek. 1966. General considerations of slow virus infections. In International Symposium on Rabies (Symposium Series on Immunobiological Standards), Karger, New York. 1:131.

31. Rowe, W. 1956. Protective effects of pre-irradiation on lymphocytic choriomeningitis infection in mice. Proc. Soc. Exp. Biol. Med. 92:194.

32. Haas, V. H., and S. E. Stewart. 1956. Sparing effect of a methopterin and guanazolo in mice infected with virus of lymphocytic choriomeningitis. Virology. 2: 511.

33. Hotchin, J., and H. Weigand. 1961. The effects of pre-treatment with x-rays on the pathogenesis of lymphocytic choriomeningitis in mice. I. Host survival, virus multiplication and leucocytosis. $J$. Immunol. 87:675.

34. East, J., D. Parrott, and J. Seamer. 1964. The ability of mice thymectomized at birth to survive infection with lymphocytic choriomeningitis virus. Virology. 22:160.

35. Hirsch, M., F. Murphy, H. Russe, and M. Hicklin. 1967. Effects of anti-thymocyte serum on lymphocytic choriomeningitis (LCM) virus infection in mice. Proc. Soc. Exp. Biol. Med. 125:980.

36. Hirsch, M., F. Murphy, and M. Hicklin. 1968. Immunopathology of lymphocytic choriomeningitis virus infection of newborn mice. Anti-thymocyte serum effects on glomerulonephritis and wasting disease. $J . \operatorname{Exp}$. Med. 127:757.

37. Dixon, F., J. Feldman, and J. Vazquez. 1961. Experimental glomerulonephritis. 
The pathogenesis of a laboratory model resembling the spectrum of human glomerulonephritis. J. Exp. Med. 113:899.

38. Lambert, P., and F. Dixon. 1968. Pathogenesis of the glomerulonephritis of NZB/W mice. J. Exp. Med. 127:507.

39. Unanue, E., and F. Dixon. 1967. Experimental glomerulonephritis: immunological events and pathogenetic mechanisms. Advan. Immunol. 6:1.

40. Fennell, Jr., R., and A. San Tamaria. 1962. Anaphylaxis in the rat. Immunohistochemical and histochemical studies of the liver. Amer. J. Pathol. 41:521.

41. Fernandes, M., T. Wiktor, and H. Koprowski. 1964. Endosymbiotic relationship between animal viruses and host cells. A study of rabies virus in tissue culture. J. Exp. Med. 120:1099. 
FIG. 2 a. Renal glomerulus from a $10 \mathrm{wk}$ old SWR/J mouse infected with LCM virus at birth. The preparation was stained with fluorescein-conjugated rabbit antiserum to mouse $7 \mathrm{~S} \gamma$-globulin. $\gamma$-Globulin is heavily deposited in mesangial areas and less heavily along peripheral walls of glomerular capillaries. Comparable results were obtained with fluorescein-conjugated rabbit antiserum to mouse $C^{\prime} 3(\beta 1 \mathrm{C}$-globulin, the third component of complement). Following absorption of fluoresceinated antisera with mouse $\mathrm{C}^{\prime} 3$ or $\gamma$-globulin, no staining occurred. Fluorescein-conjugated rabbit antisera to mouse albumin or rat fibrinogen did not stain the glomerulus.

Frg. $2 b$. Renal glomerulus from a $10 \mathrm{wk}$ old SWR/J mouse inoculated at birth with a cleared $10 \%$ suspension of isologous normal brain. Preparation stained with fluorescein-conjugated rabbit antiserum to mouse $7 \mathrm{~S} \gamma$-globulin. Glomerulus at center of figure contains no detectable $\gamma$-globulin. Surrounding tubules are indicated by natural autofluorescence brought out by overexposure. 
MICHAEL B. A. OLDSTONE AND FRANK J. DIXON
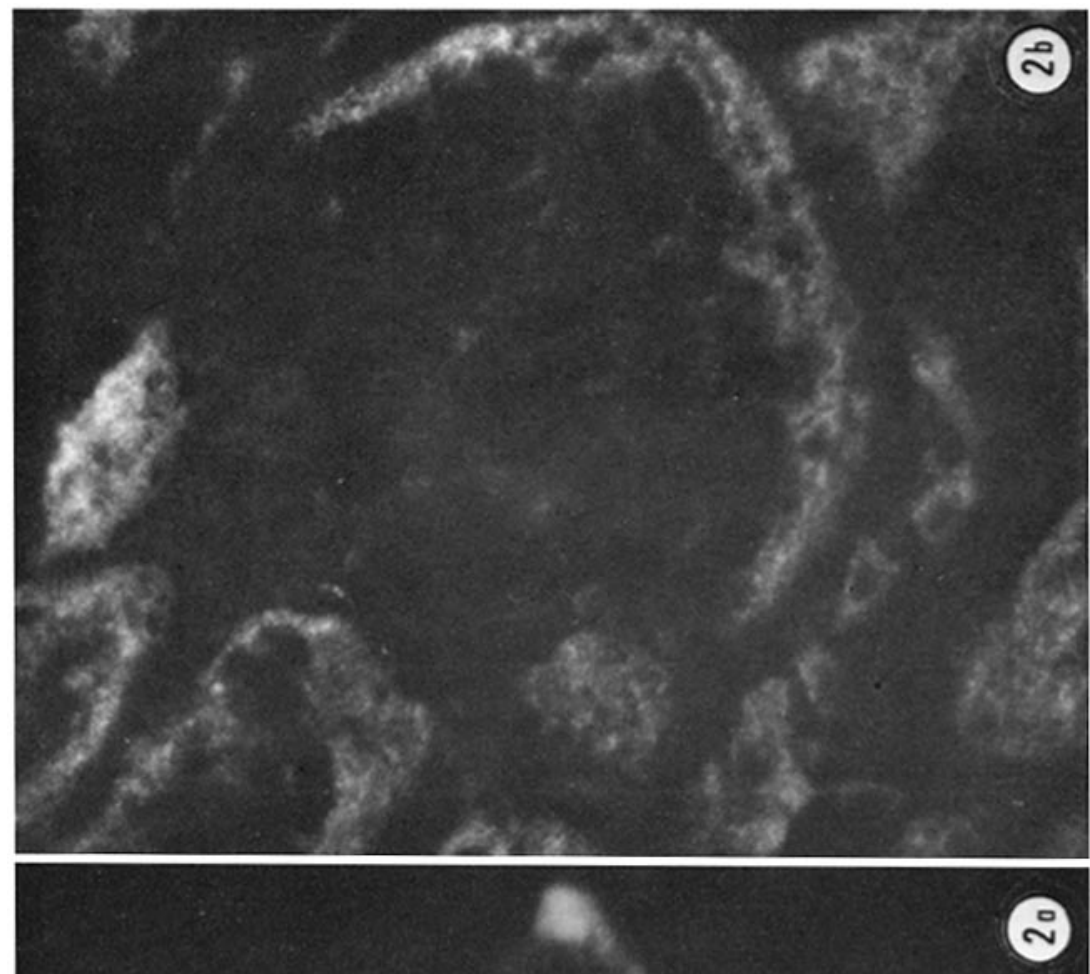

ํำ 

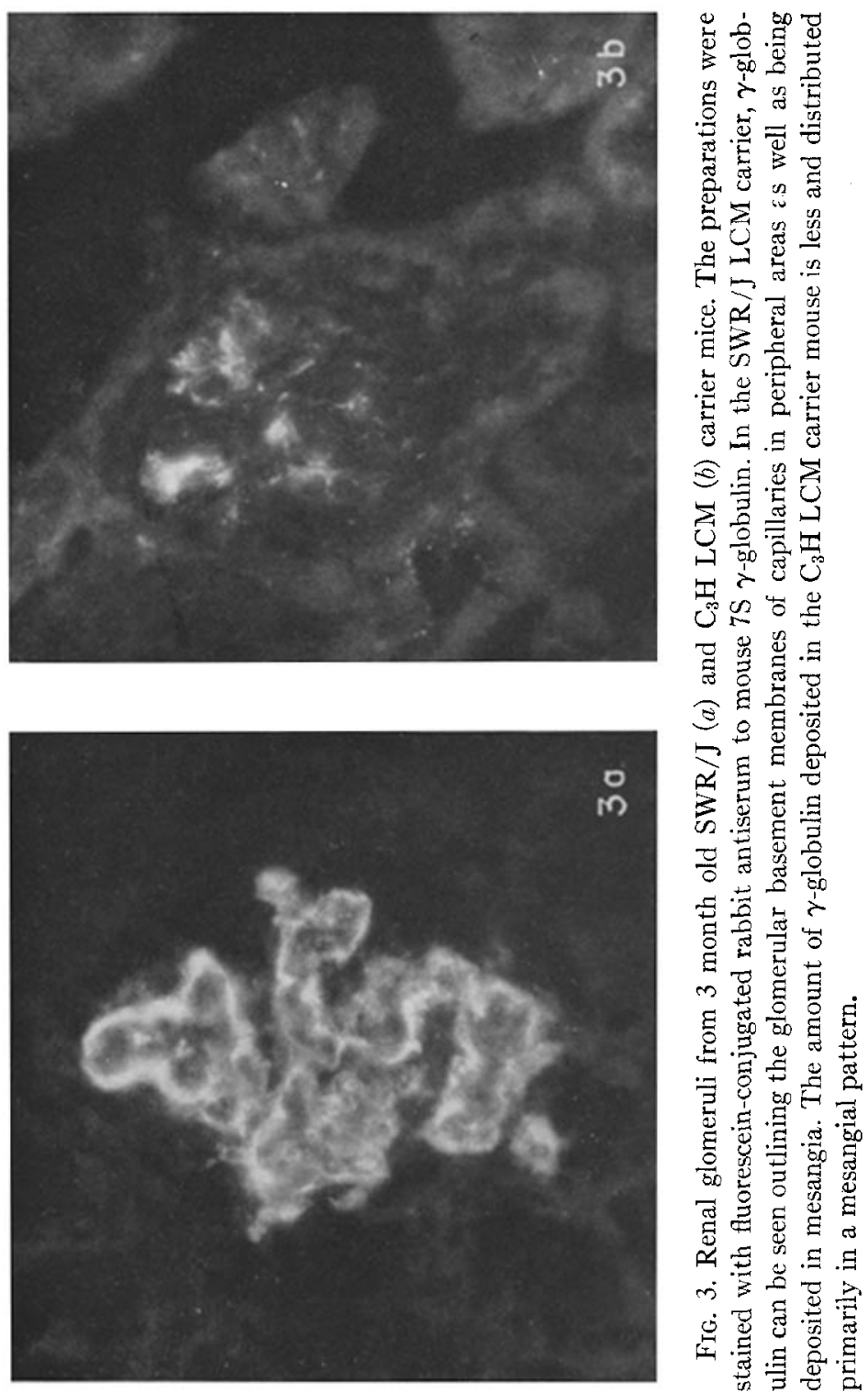

o

FIG. 4. Light photomicrographs of glomeruli stained with periodic acid-Schiff (PAS), a. Glomerulus from a 3 month old SWR/J carrier mouse showing marked basement membrane thickening (arrow) and intracapillary hyalinization. $b$. Glomerulus from a 5 month old SWR/J LCM carrier mouse showing capillary occlusion by deposits of PAS-staining material. (arrow). 
MICHAEL B. A. OLDSTONE AND FRANK J. DIXON

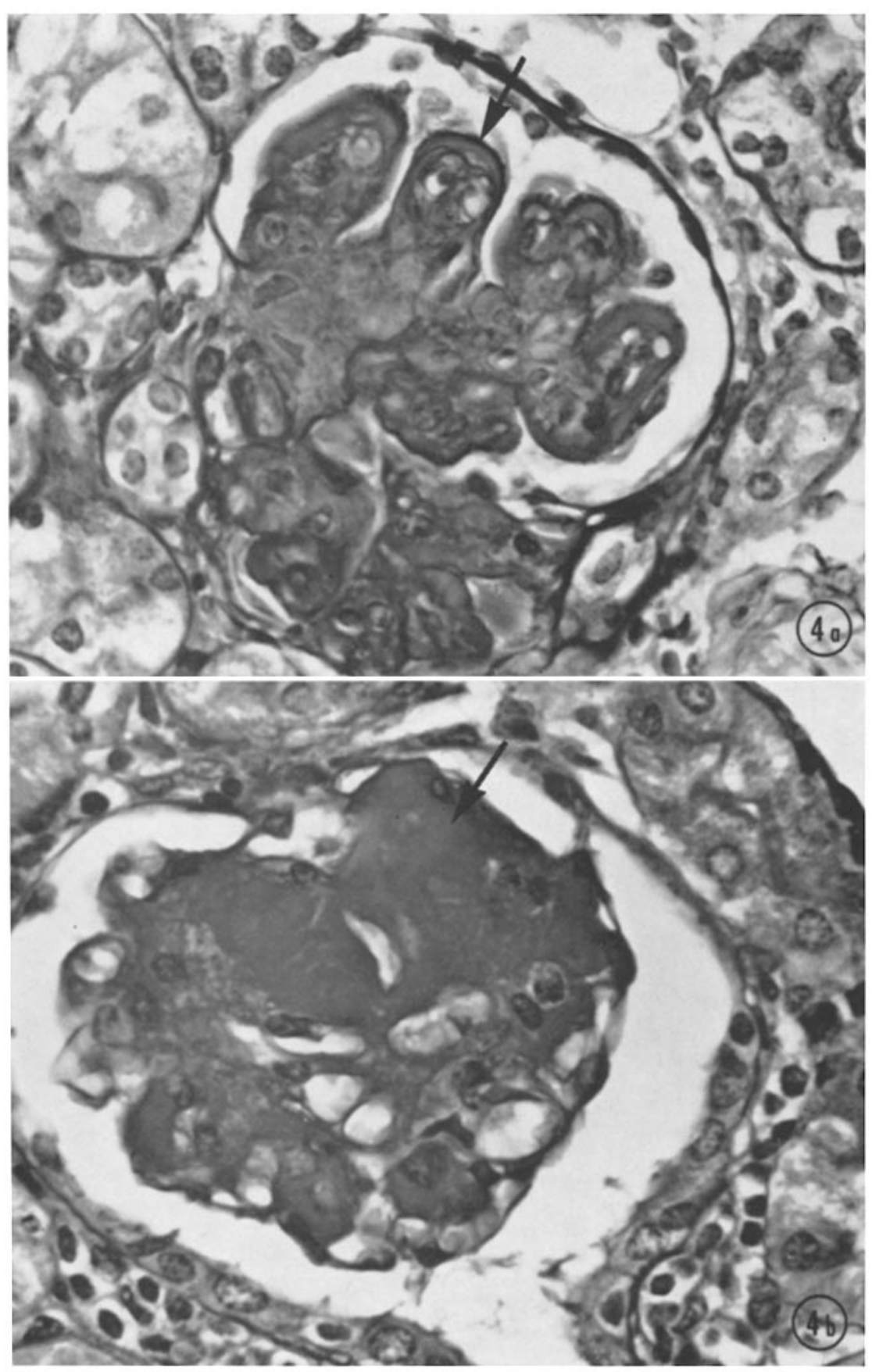




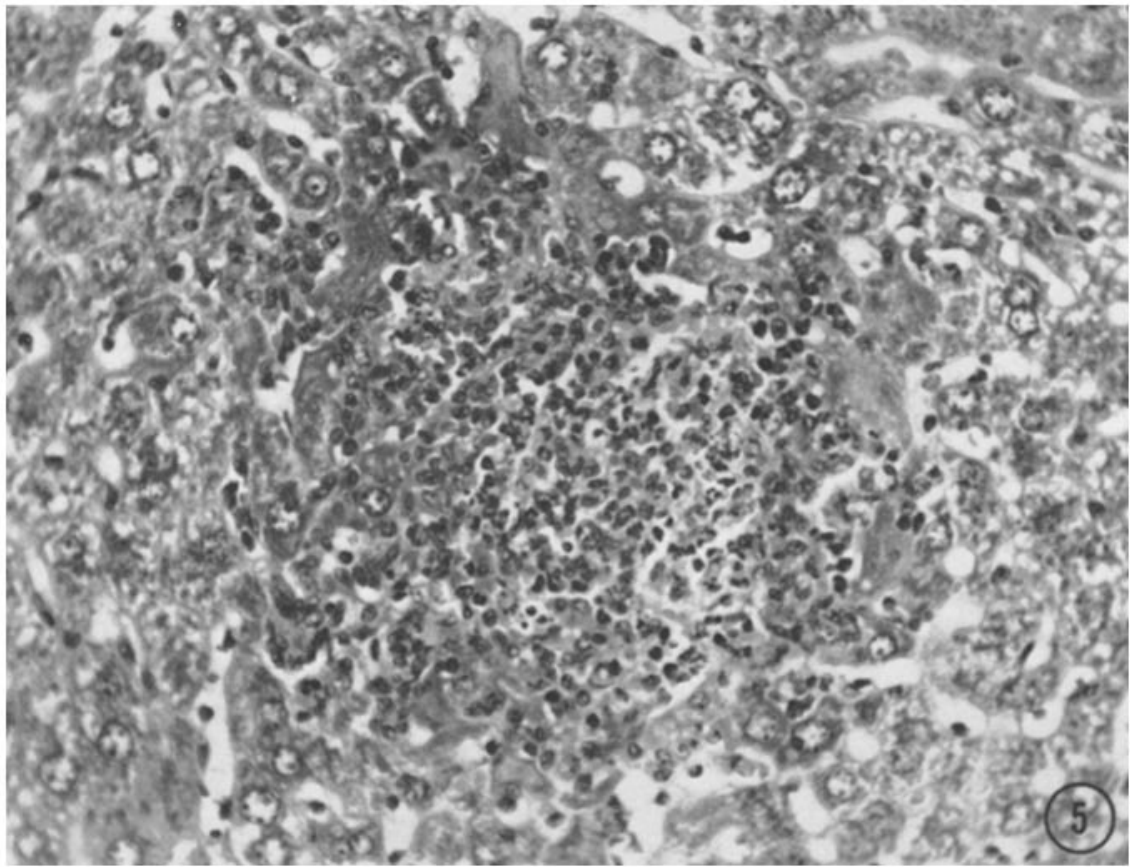

Frg. 5. Light photomicrograph of a hematoxylin and eosin-stained liver section from a 10 month old B10D2 old LCM carrier mouse showing area of focal necrosis with infiltrating acute and chronic inflammatory cells. Similar foci were scattered throughout the liver without detectable relationship to hepatic architecture.

FIG. 6. Light photomicrographs of hematoxylin and eosin-stained tissues from a 10 wh old SWR/J LCM carrier mouse. Interstitial predominantly round cell infiltrations are seen in $a$, kidney, $b$, liver, $c$, lung, $d$, omental fat. 


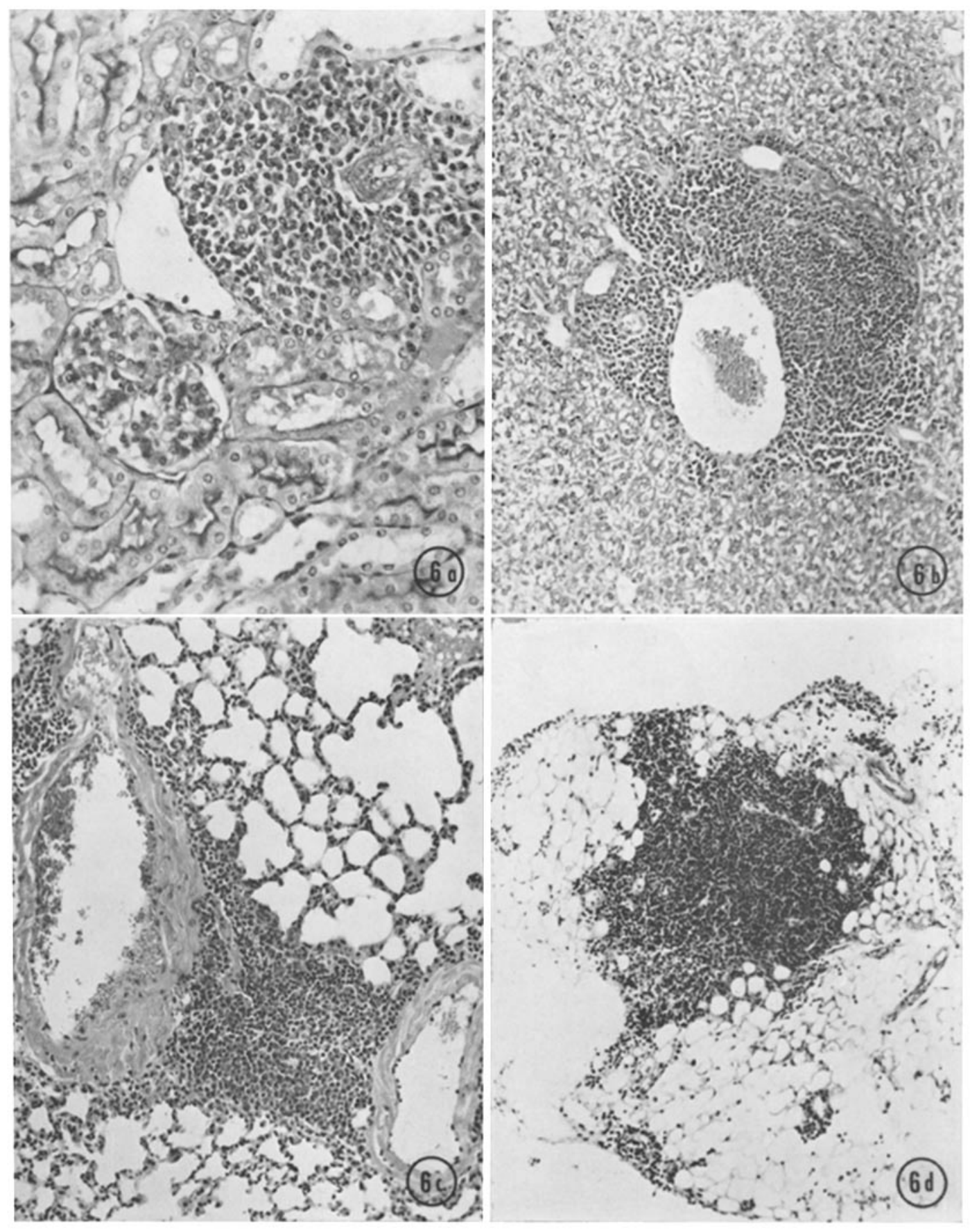

